\title{
A Magnetic Bead-Based DNA Extraction Protocol Suitable for High-Throughput Genotyping in Shrimp Breeding Programs
}

\author{
Cheryl K.Y. Tan ${ }^{1,2}$, Jeff A. Cowley ${ }^{1,3 *}$ (D), Dean R. Jerry ${ }^{1,2,4}$
}

\author{
${ }^{1}$ Australian Research Council (ARC) Research Hub for Advanced Prawn Breeding, James Cook University, Townsville, \\ QLD 4811, Australia. \\ ${ }^{2}$ Centre for Sustainable Tropical Fisheries and Aquaculture, College of Science and Engineering, James Cook University, \\ Townsville, QLD 4811, Australia. \\ ${ }^{3}$ Aquaculture, CSIRO Agriculture and Food, Queensland Bioscience Precinct, St. Lucia, QLD 4067, Australia. \\ ${ }^{4}$ Tropical Futures Institute, James Cook University Singapore, Singapore.
}

\section{Article History}

Received November 1, 2019

Accepted December 4, 2019

First Online December 6, 2019

\section{Corresponding Author \\ Tel.: +61732142527 \\ E-mail: jeff.cowley@csiro.au}

\section{Keywords}

Shrimp

Prawn

DNA extraction method

Magnetic bead

High-throughput

Genetic analysis

\begin{abstract}
Due to their convenience, magnetic bead-based nucleic acid extraction kits are commonly used in shrimp genotyping and pathogen screening applications. However, in advanced breeding programs requiring the testing of many thousands of shrimp, their cost can be prohibitive. Various permutations of different Proteinase $\mathrm{K}$ digestion, tissue lysis and bead washing buffers as well as magnetic bead types were thus evaluated to devise a high-throughput shrimp DNA extraction (SDE) protocol capable of recovering high-purity DNA using a KingFisher ${ }^{\mathrm{TM}}$ Flex Magnetic Particle processor. When genotyped using a MassARRAY ${ }^{\circ}$ platform (Agena Bioscience) requiring 60-61 genome regions to be co-amplified in a single multiplexed PCR, DNA extracted from shrimp muscle tissue using either the SDE protocol or a commercial kit generated comparable single-nucleotide polymorphism (SNP) call data. The SDE protocol also extracted high-purity DNA from salmon fin clips. It thus offers potential to markedly reduce the costs of large-scale genotyping in shrimp and salmon breeding programs.
\end{abstract}

\section{Introduction}

DNA extraction methods involving various levels of sophistication continue to be developed and refined to meet yield, purity, throughput and cost requirements for genotyping, genome sequencing and pathogen screening applications across diverse species and tissue types (Chomczynski \& Sacchi, 1987; Marko, Chipperfield \& Birnboim, 1982; Ali et al., 2017; Dierens, Henshall \& Sellars, 2014; Planella et al., 2017; Psifidi et al., 2010; Psifidi et al., 2015; Rao, Arnold \& Cowley 2010; Zheng et al., 2015; Inglis et al., 2018). Since being developed in the mid-1990s (Deggerdal \& Larsen, 1997; Hawkins et al., 1994; Kang et al., 2009; Levison et al., 1998; Rudi et al., 1997), magnetic bead-based methods have increasingly been adopted due to the convenience and widespread availability of commercial kits, their ability to generate high-purity nucleic acid and their amenability to automated high-throughput instruments such as the KingFisher ${ }^{\mathrm{TM}}$ Flex Magnetic Particle processor (Nagy et al., 2005; Witt et al., 2012; URL1). While convenient, the expense of using such kits can be prohibitive in research and industrial applications needing to, for example, track the pathogen infection status, pedigrees and genetic traits of many thousands of individuals for the purposes of selecting elite breeding lines. To dissuade users from copying them, such kits also typically employ minimally-defined proprietary buffer formulations optimized to specific species and tissue types (Claassen et al., 2013; Dauphin, Moser \& 
Bowen, 2009a, Dauphin et al., 2009b; Dauphin et al., 2011; Lim et al., 2018; Mertens et al., 2014). Despite this and due to most of the key reagents used in magnetic bead-based nucleic acid extraction protocols such as Proteinase $\mathrm{K}$ (ProK), guanidine hydrochloride (GuHCl)/thiocyanate (GuSCN) and Triton-X100 being relatively inexpensive when purchased in sizeable quantities, buffer sets that can be used to reduce extraction costs continue to be reported for different species and tissue types (Kang et al., 2009; Li et al., 2017; Mertens et al., 2014; Psifidi et al., 2010; Psifidi et al., 2015).

To grow the Black tiger shrimp (Penaeus monodon) farming industry in Australia, programs are underway to generate elite breeding lines through the use of genetic tools to manage diversity and select for desirable production traits (Alam \& Pálsson, 2016; Baranski et al., 2014; Dekkers 2012; Guppy et al., 2018; Huerlimann et al., 2018; Lu et al., 2017; Robledo et al., 2017; Sellars et al., 2012; Waqairatu et al., 2012). To help reduce the high cost of genotyping and pathogen screening in these programs, described here are data leading to the development of a buffer set optimized for automated 96-well plate-based extraction of high-purity DNA from shrimp and fish tissues using a KingFisher processor.

\section{Materials and Methods}

\section{Tissue Sources}

Black tiger shrimp (Penaeus monodon) were obtained from the CSIRO Bribie Island Research Centre,
QLD, Australia. Shrimp were placed in zip-lock plastic bags, euthanized by submersion in wet ice and stored at $-20^{\circ} \mathrm{C}$ until rapidly thawed for use. Fin clips from Atlantic salmon (Salmo salar) were obtained from an aquaculture farm in Tasmania, Australia. Individual fin clips were stored in 95\% ethanol in $2 \mathrm{ml}$ screw cap tubes at $4^{\circ} \mathrm{C}$ until used.

\section{Trials to Define Shrimp DNA Extraction (SDE) Protocol Buffers}

Initially, a set of buffers developed to extract highpurity DNA from white blood cells (WBC DNA Protocol; Psifidi et al., 2015) was compared to those used in the MagJET Genomic DNA Kit (MGD Kit, Cat. no. K2722, Thermo Scientific). As detailed in Table 1, buffer volumes used for tissue digestion and lysis and for DNA bead binding, washing and elution followed those described in Protocol E of the MGD Kit Manual (URL2). All extractions were undertaken using the automated KingFisher processor (URL1, Thermo Fisher Scientific). Bindlt Software V4.0 (URL3, Thermo Scientific) was used to run the Tissue DNA KingFisher ${ }^{\mathrm{TM}}$ Flex 96 program (KF_TissueDNA_Flex96.bdz file download available at URL4, Thermo Fisher Scientific) used to control the mechanics of each step on the KingFisher processor. Based on prior experience in using the MGD Kit to reliably obtain high-purity DNA $\left(A_{260 / 230 n m}>1.95\right)$ from shrimp muscle tissue, the Flex 96 program .bdz file was modified to include a third Wash Buffer 2 step. For the WBC DNA protocol, buffer volumes were adjusted proportionally to match those used with the MGD Kit.

Table 1. MagJET Genomic DNA (MGD) Kit (Thermo Fisher) buffer and reagent volumes used for tissue digestion and DNA bead binding, washing and elution on the KingFisher ${ }^{\mathrm{TM}}$ Flex Magnetic Particle processor controlled by an amended Flex 96 Program

\begin{tabular}{|c|c|c|c|c|}
\hline \multicolumn{3}{|c|}{ Tissue DNA KingFisher TM Flex 96 Program } & \multicolumn{2}{|c|}{ Buffers and other reagents } \\
\hline $\begin{array}{l}\text { Program } \\
\text { step no, }\end{array}$ & $\begin{array}{l}\text { Program } \\
\text { step name }\end{array}$ & Plate type used & Name & Amounts per plate well \\
\hline & & $\begin{array}{l}\text { Eppendorf deep-well } \\
\text { 96-well plate }\end{array}$ & Tissue digest* & $\begin{array}{c}\text { 12-20 mg shrimp muscle tissue } \\
200 \mu \mathrm{l} \text { ProK Digestion Buffer } \\
20 \mu \mathrm{l} 20 \mathrm{mg} / \mathrm{ml} \text { Proteinase } \mathrm{K}\end{array}$ \\
\hline 1 & Lysate & $\begin{array}{l}\text { KingFisher Flex deep- } \\
\text { well 96-well plate }\end{array}$ & $\begin{array}{l}\text { Tissue lysate } \\
100 \% \text { isopropanol } \\
\text { Magnetic beads }\end{array}$ & $\begin{array}{c}200 \mu \mathrm{l} \text { digested tissue supernatant } \\
300 \mu \mathrm{l} \text { Lysis Buffer } \\
20 \mu \mathrm{l} 10 \mathrm{mg} / \mathrm{ml} \text { RNase A } \\
400 \mu \mathrm{l} \\
25 \mu \mathrm{l} \text { (or } 3,6,12,24 \mu \mathrm{l} \text { as tested) }\end{array}$ \\
\hline 2 & Wash 1 & KingFisher Flex deep- & Wash Buffer 1 & $700 \mu \mathrm{l}$ \\
\hline 3 & Wash 2-1 & well 96-well plates & Wash Buffer 2 & $700 \mu \mathrm{l}$ \\
\hline 4 & Wash 2-2 & & Wash Buffer 2 & $700 \mu l$ \\
\hline 5 & Wash 2-3 & & Wash Buffer 2 & $700 \mu \mathrm{l}$ \\
\hline 6 & Elution & $\begin{array}{l}\text { KingFisher Flex } 96 \mathrm{KF} \\
\text { plate }\end{array}$ & $\begin{array}{l}\text { Low-EDTA } \\
\text { TE Buffer }\end{array}$ & $80 \mu \mathrm{l}$ \\
\hline
\end{tabular}

\footnotetext{
* Tissue digest undertaken prior to being added to the Tissue lysate as Step 1 of the Program used to run the KingFisher processor. Note that the automated Flex 96 Program Steps 1 to 6 are performed by the KingFisher processor (robot) using a carousel of plates preloaded with each buffer.
} 
This allowed for DNA to be extracted by both methods in the same plate under identical automated run conditions.

To develop the shrimp DNA extraction (SDE) protocol, a series of trials were run to optimize buffer compatibilities (Table 2). The SDE protocol was standardised to use 96-well plates and extract DNA from 12-20 mg tissue samples in $200 \mu \mathrm{l}$ Tissue Digestion Buffer (ProK Digestion Buffer) containing $20 \mu \mathrm{l}$ cut 20 $\mathrm{mg} / \mathrm{ml}$ Proteinase $\mathrm{K}$ (ProK). To expedite digestion, the plate was shaken $(200 \mathrm{rpm})$ at $56^{\circ} \mathrm{C}$ for $3 \mathrm{~h}$ using a Ratek OM11 Medium Orbital Shaking Incubator. In trials to assess various buffer permutations, larger amounts of minced muscle tissue were digested similarly in sterile $50 \mathrm{ml}$ screw-cap centrifuge tubes using proportionally increased volumes of ProK Digestion Buffer. After centrifuging briefly to pellet residual particulate matter, $200 \mu \mathrm{l}$ aliquots of clarified digest were transferred to each well of a 96-well deep-well plate containing $300 \mu \mathrm{l}$ Lysis Buffer and $20 \mu \mathrm{l} 10 \mathrm{mg} / \mathrm{ml}$ RNase A. The plate was shaken gently at room temp for 10 min using a Thermomixer (Eppendorf) before being loaded into the carousel of the KingFisher processor. Typically, 2 of 4 replicate wells of each lysate were extracted to assess DNA extraction reproducibility. To extract DNA from salmon tissue, single fin tips (35-44 mg) were digested in $1 \mathrm{ml}$ ProK Digestion Buffer, with $200 \mu \mathrm{l}$ aliquots of clarified digest then transferred to 4 replicate wells to be extracted as for shrimp tissue.

To optimise the SDE protocol, 4 different ProK Digestion Buffer formulations [ProK Buffer 1a $(25 \mathrm{mM}$ Tris- $\mathrm{HCl}$, 25 mM Na2-EDTA, $2 \mathrm{M} \mathrm{GuHCl}, 5 \mathrm{mM} \mathrm{CaCl}_{2}, 0.5 \%$ Triton X-100, 1\% N-Lauroylsarcosine, pH 7.5), ProK Buffer $1 b$ ( $2 \times$ concentration of 1a) (Psifidi et al., 2015), ProK Buffer 2 (30 mM Tris-HCl, 30 mM Na2-EDTA, $0.8 \mathrm{M}$ GuHCl, 0.5\% Triton X-100, 5\% Tween-20, pH 5.3) and ProK Buffer 3 (30 mM Tris-HCl, 10 mM Na2-EDTA, 3 M GuHCl, 0.5\% Triton X-100, 5\% Tween-20, pH 8.0)] were compared to that provided in the MGD Kit. Initially these buffers were evaluated with either the MGD Kit buffers and magnetic beads or the WBC DNA protocol buffers used with Silanol magnetic beads (Table 2 Trial 1A; Table 3). As DNA was extracted at substantially higher yields and purity using the MGD Kit buffers and beads (see below), each buffer used in the WBC DNA protocol was evaluated systematically for its compatibility with the MGD Kit buffers. When DNA yields and/or purity were unacceptably low, the suspected incompatible buffer was modified and re-evaluated.

The outcome of these buffer optimization trials was a SDE protocol that used ProK Buffer 1b, SDE Lysis Buffer (50 mM Tris-HCl, 25 mM Na2-EDTA, 6 M GuSCN, $3 \%$ Triton X-100, 6\% N-Lauroylsarcosine, pH 5.5), a modified SDE Wash Buffer $1(25 \mathrm{mM}$ Tris- $\mathrm{HCl}, 1.8 \mathrm{M}$ GuHCl, 75\% EtOH, pH 6.6) and a modified SDE Wash Buffer 2 (10 mM Tris- $\mathrm{HCl}, 100 \mathrm{mM} \mathrm{NaCl}, 80 \% \mathrm{EtOH}, \mathrm{pH}$ 6.6). To help preserve DNA integrity during long term storage, DNA was eluted from beads using low-EDTA TE
Buffer (10 mM Tris-HCl pH 7.5, 0.1 mM Na2-EDTA) rather than water. The 4 commercially-available magnetic bead types tested for their compatibility with the SDE protocol buffers are detailed in Table 3.

\section{DNA Yield and Purity Assessments}

To assess DNA yield and relative purity, $2 \mu \mathrm{l}$ each extract was assessed in triplicate on a Nanodrop ND8000 UV spectrophotometer (Thermo Scientific 2010; Gallagher 2011). The $A_{260 / 280 n m}$ ratio provided an estimate of levels of protein contamination and the

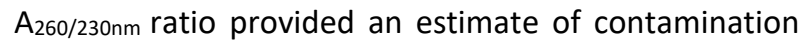
with salts, with ratios $\geq 1.8$ and $\geq 2.0$, respectively, at $\mathrm{pH}$ 7.5 considered to represent high-purity DNA (URL5).

\section{SNP Genotyping}

To validate its amenability to downstream analyses, shrimp DNA extracted using the SDE protocol in combination with the AccuBead, Silanol or Sera-Mag bead magnetic bead types (Table 3) was genotyped using 2 MassARRAY panels (Sellars et al., 2012, URL6, Agena Bioscience) at the Australian Genome Research Facility (AGRF), Brisbane, Australia. Each MassARRAY panel was in routine use at the time for tracking pedigrees and genetic diversity within cohorts of $P$. monodon, and had the capacity to assign SNPs in 60 to 61 PCR products amplified in a single reaction using a highly multiplexed set of iPLEX PCR primer pairs (Henshall, Dierens, \& Sellars 2014; Sellars et al., 2012, Agena Bioscience). In this analysis, each SDE protocol/bead type combination was used to extract DNA from 22-24 replicates of a bulk digest of muscle tissue from a single shrimp and was compared to DNA extracted from muscle of the same shrimp using the MGD Kit. Prior to being genotyped, the relative purity and concentration of each DNA was determined, and it was normalised to $25 \mathrm{ng} / \mu \mathrm{l}$ in low-EDTA TE Buffer to negate SNP call differences due to concentrationrelated factors.

\section{Results and Discussion}

\section{Comparison of MGD Kit and WBC DNA Protocols}

In initial comparisons, DNA was extracted in duplicate using equal weights of abdominal muscle tissue from the same shrimp and either the MGD Kit or the WBC DNA protocol used with Silanol beads (Psifidi et al., 2015). The volume of each WBC DNA protocol buffer was adjusted proportionally so that DNA could be extracted under identical KingFisher processor run conditions optimized for use with the MGD Kit buffers (Table 1, Table 2 Trial 1A, Figure 1A). Duplicate extractions using either method generated uniform DNA yields. However, yields obtained with the WBC protocol buffers $(49.6 \pm 2.3 \mathrm{ng} / \mu \mathrm{l})$ were $\sim 2.6$-fold lower than with 
Table 2. Trials run to optimise the SDE protocol

\begin{tabular}{|c|c|c|c|c|c|c|c|c|c|}
\hline Trial & Extract ID & $\begin{array}{c}\text { Tissue } \\
\text { weight } \\
\text { (mg) }\end{array}$ & Bead type & $\begin{array}{c}\text { Bead } \\
\text { volume } \\
(\mu \mathrm{l})\end{array}$ & $\begin{array}{l}\text { ProK } \\
\text { Buffer } \\
\text { Type } \\
\end{array}$ & $\begin{array}{l}\text { Pooled } \\
\text { ProK } \\
\text { Buffer }\end{array}$ & $\begin{array}{l}\text { Lysis } \\
\text { Buffer }\end{array}$ & $\begin{array}{c}\text { Wash } \\
\text { Buffer } 1\end{array}$ & $\begin{array}{c}\text { Wash } \\
\text { Buffer } 2\end{array}$ \\
\hline \multirow[t]{2}{*}{$1 \mathrm{~A}$} & 1 & 12 & Sil & 25 & WBC & $\mathrm{N}$ & WBC & WBC & WBC \\
\hline & 2 & 12 & MGD & 25 & MGD & $\mathrm{N}$ & MGD & MGD & MGD \\
\hline \multirow[t]{5}{*}{$1 B$} & 3 & 20 & MGD & 25 & MGD & $\mathrm{Y}$ & MGD & MGD & MGD \\
\hline & 4 & & & & $1 a$ & & & & \\
\hline & 5 & & & & $1 b$ & & & & \\
\hline & 6 & & & & 2 & & & & \\
\hline & 7 & & & & 3 & & & & \\
\hline \multirow[t]{6}{*}{$2 \mathrm{~A}$} & 8 & 12 & MGD & 25 & $1 b$ & $\mathrm{Y}$ & MGD & MGD & MGD \\
\hline & 9 & & & & & & WBC & MGD & MGD \\
\hline & 10 & & & & & & WBC & MGD & WBC \\
\hline & 11 & & & & & & MGD & WBC & MGD \\
\hline & 12 & & & & & & WBC & WBC & MGD \\
\hline & 13 & & & & & & MGD & MGD & WBC \\
\hline \multirow[t]{2}{*}{$2 B$} & 14 & 13 & MGD & 25 & $1 b$ & $Y$ & MGD & MGD & MGD \\
\hline & 15 & & & & & & MGD & SDE & MGD \\
\hline \multirow[t]{3}{*}{$2 \mathrm{C}$} & 16 & 12 & MGD & 25 & $1 b$ & $\mathrm{Y}$ & WBC & SDE & SDE \\
\hline & 17 & & & & & & WBC & MGD & WBC \\
\hline & 18 & & & & & & WBC & WBC & MGD \\
\hline \multirow[t]{24}{*}{3} & 19 & 20 & MGD & 3 & MGD & $\mathrm{Y}$ & MGD & MGD & MGD \\
\hline & 20 & & & 6 & & & & & \\
\hline & 21 & & & 12 & & & & & \\
\hline & 22 & & & 24 & & & & & \\
\hline & 23 & & MGD & 3 & $1 b$ & $\mathrm{Y}$ & WBC & SDE & SDE \\
\hline & 24 & & & 6 & & & & & \\
\hline & 25 & & & 12 & & & & & \\
\hline & 26 & & & 24 & & & & & \\
\hline & 27 & & Accu & 3 & & & & & \\
\hline & 28 & & & 6 & & & & & \\
\hline & 29 & & & 12 & & & & & \\
\hline & 30 & & & 24 & & & & & \\
\hline & 31 & & $\mathrm{Ag}$ & 3 & & & & & \\
\hline & 32 & & & 6 & & & & & \\
\hline & 33 & & & 12 & & & & & \\
\hline & 34 & & & 24 & & & & & \\
\hline & 35 & & Sil & 3 & & & & & \\
\hline & 36 & & & 6 & & & & & \\
\hline & 37 & & & 12 & & & & & \\
\hline & 38 & & & 24 & & & & & \\
\hline & 39 & & SM & 3 & & & & & \\
\hline & 40 & & & 6 & & & & & \\
\hline & 41 & & & 12 & & & & & \\
\hline & 42 & & & 24 & & & & & \\
\hline
\end{tabular}

Abbreviations: WBC = White Blood Cell protocol (Psifidi et al., 2015); SDE = Shrimp DNA Extraction protocol; MGD = MagJET Genomic DNA protocol

Bead types: MGD = MGD Kit beads; Accu = AccuBead silica-coated beads; Sil = Silanol functional beads; SM = Sera-Mag SpeedBead Carboxylate-modified beads; $\mathrm{Ag}=$ Agencourt AMPure XP beads ProK $=$ Proteinase $\mathrm{K}$

the MGD Kit $(131.0 \pm 6.5 \mathrm{ng} / \mu \mathrm{l})$ (Figure $1 \mathrm{~A})$. While the $\mathrm{A}_{260 / 280 \mathrm{~nm}}$ ratio of the WBC protocol DNA was only slightly lower $(1.80 \pm 0.03)$ than the MGD Kit DNA (1.88 $\pm 0.02)$, its $A_{260 / 230} \mathrm{~nm}$ ratio was non-ideal $(1.25 \pm 0.03)$ (Figure $1 \mathrm{~A})$. The lower DNA yield and purity suggested WBC protocol buffer incompatibilities with shrimp muscle tissue and/or the KingFisher processor bead binding and washing program steps that either compromised DNA binding to the magnetic beads or promoted its premature detachment and the carryover of salts (URL5). To identify which buffers were incompatible, each was evaluated systematically and modified as required.

\section{Proteinase K Digestion Buffers}

To assess the influence of different ProK Digestion Buffers, the WBC DNA ProK Buffer at $1 \times$ (ProK Buffer 1a) 
Table 3. Commercially-available magnetic bead types assessed

\begin{tabular}{|c|c|c|c|}
\hline Name & Vendor (Australia) & Catalogue No. & $\begin{array}{c}\text { Cost/sample* } \\
\text { (AUD) }\end{array}$ \\
\hline Silanol functionalized beads & $\begin{array}{l}\text { Advance Scientific } \\
\text { Products }\end{array}$ & PMSI-H1.0-5 & $\$ 0.25$ \\
\hline AccuBead ${ }^{\mathrm{TM}}$ Silica coated & Bioneer Pacific & TA-1010-1 & $\$ 0.02$ \\
\hline $\begin{array}{l}\text { Sera-Mag SpeedBead Carboxylate- } \\
\text { modified }\end{array}$ & GE Life Sciences & 65152105050250 & $\$ 0.09$ \\
\hline Agencourt AMPure XP & $\begin{array}{l}\text { Beckman Coulter Life } \\
\text { Sciences }\end{array}$ & A63881 & $\$ 0.02$ \\
\hline
\end{tabular}

* Approximate minimum cost based on the use of $3 \mu \mathrm{l}$ beads/DNA extraction in 2019.

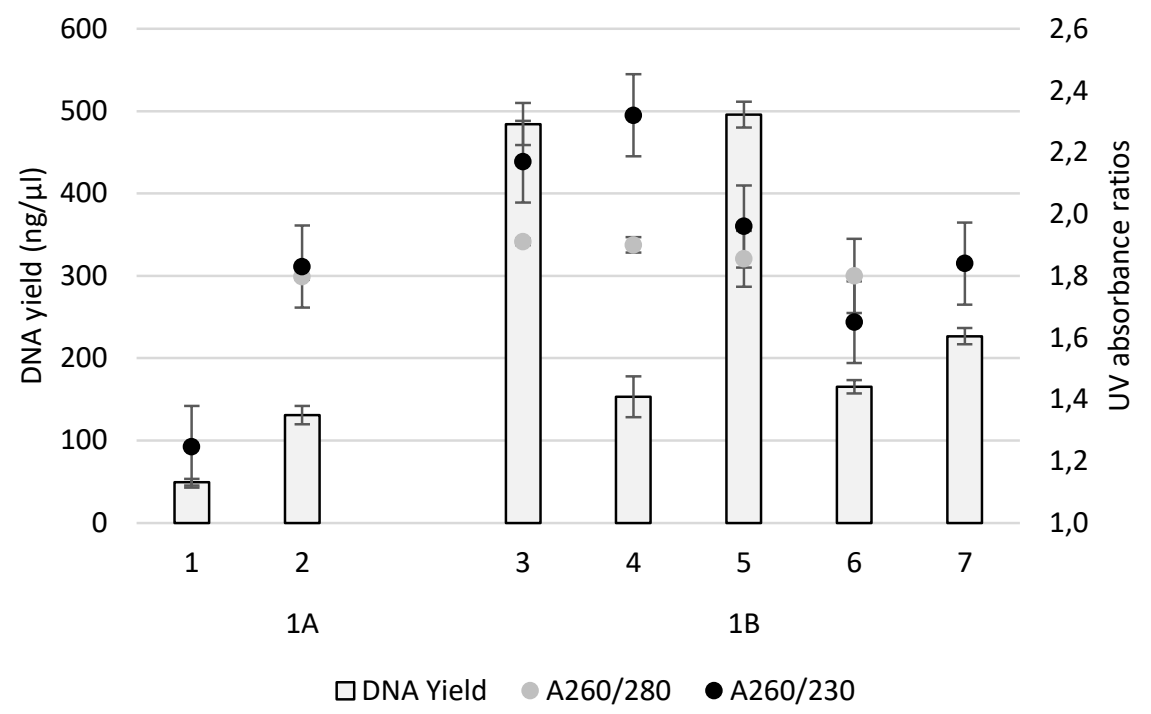

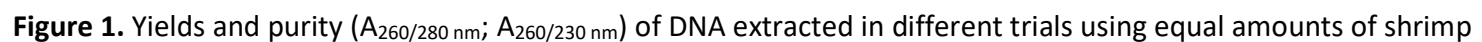
abdominal muscle tissue and various DNA extraction reagent permutations as described in Table 2. Trial $1 \mathrm{~A}$ compared the WBC DNA (1) or MGD Kit (2) extraction protocol buffer sets. The WBC DNA protocol employed Silanol functional beads and data points represent the mean \pm SD of duplicate extractions. Trial 1B compared the MGD Kit (3) extraction protocol to this protocol used with the Kit ProK buffer substituted by ProK Buffers 1a (4), 1b (5), 2 (6) or 3 (7), with data points representing the mean \pm SD of duplicate extractions.

and $2 \times$ concentration (ProK Buffer 1 b) as well as 2 other buffer recipes ( 2 and 3 ) were compared against that used in the MGD Kit. For this, $50 \mathrm{mg}$ shrimp muscle tissue was digested in $0.5 \mathrm{ml}$ each buffer containing 50 $\mu \mathrm{l} 20 \mathrm{mg} / \mathrm{ml}$ ProK, with duplicate $200 \mu \mathrm{l}$ aliquots of clarified digest then processed in the KingFisher processor using MGD Kit Lysis and Wash Buffers (Table 2 Trial 1B, Figure 1B). UV spectral analysis showed DNA yields with the MGD Kit ProK Digestion Buffer (406.2 \pm $67.6 \mathrm{ng} / \mu \mathrm{l})$ and ProK Buffer $1 \mathrm{~b}(399.3 \pm 79.4 \mathrm{ng} / \mu \mathrm{l})$ to be 2- to 3-fold higher than those obtained using the other 3 buffers assessed. A260/280 nm ratios with DNA extracted using any of the 5 buffers were $>1.8$, but highest with the MGD Kit buffer $(1.93 \pm 0.02)$ (Figure 1B). A260/230 nm ratios were highest using ProK Buffer 1a $(2.39 \pm 0.07)$, but also $\geq 2$ with DNA extracted using either the MGD Kit buffer or ProK Buffer $1 b$ (Figure 1B). The DNA yield and purity data obtained in this trial suggested that ProK Buffer $1 b$, which contained the highest concentration of
GuHCl (4 M), compared well with the MGD Kit ProK buffer when used together with the MGD Kit magnetic beads and Lysis/Wash Buffers.

\section{Lysis Buffer and Wash Buffers}

As ProK Buffer $1 \mathrm{~b}$ generated high yields of highpurity DNA when used together with MGD Kit lysis and wash buffers, it was selected as the basis for identifying compatible alternative lysis and wash buffers. To examine this, $24 \mathrm{mg}$ amounts of muscle tissue from the same shrimp were digested in $400 \mu \mathrm{l}$ ProK Buffer $1 \mathrm{~b}$ together with $40 \mu \mathrm{l} 20 \mathrm{mg} / \mathrm{ml}$ ProK, with duplicate 200 $\mu \mathrm{l}$ aliquots of clarified digest then extracted using various permutations of MGD Kit and WBC protocol lysis and wash buffers (Table 2 Trial 2A, Figure 1). Compared to extractions with the MGD Kit buffers (18.0 \pm 2.1 $\mathrm{ng} / \mu \mathrm{l})$, a higher DNA yield was obtained with the WBC DNA protocol lysis buffer used together with the MGD 
Kit wash buffers $(30.0 \pm 0.3 \mathrm{ng} / \mu \mathrm{l})$. While DNA purity ( $A_{260 / 280} \mathrm{~nm} ; A_{260 / 230} \mathrm{~nm}$ ratios) was somewhat reduced $(1.88 \pm 0.15 ; 2.06 \pm 0.11)$ compared to that extracted using the MGD Kit buffers $(1.92 \pm 0.12 ; 2.51 \pm 0.41)$, they were considered acceptable. Likewise, the WBC protocol Wash Buffer 2 did not substantially compromise DNA yield or purity (MGD kit/WBC protocol $\mathrm{A}_{260 / 280 \mathrm{~nm}} 1.89 \pm 0.02 / 1.87 \pm 0.15 ; \mathrm{A}_{260 / 230 \mathrm{~nm}} 2.25 \pm$ $0.08 / 2.19 \pm 0.16$ ). However, DNA yields obtained using the WBC protocol Wash Buffer 1 were unacceptable low $(2.7 \pm 1.0 \mathrm{ng} / \mu \mathrm{l})$.

To examine wash buffer compatibilities with the optimised ProK Buffer $1 \mathrm{~b}$ and Lysis buffer, the propanol component of Wash Buffers 1 and 2 was replaced with higher concentrations of ethanol as specified for use in the MGD Kit wash buffers. Extraction using the revised WBC protocol Wash Buffer 1 improved DNA yield by $\sim 40 \%$ with only a small reduction in DNA purity based on A $260 / 230 \mathrm{~nm}$ values (Table 2 Trial 2B, Figure 2). Extraction using ethanol-containing Wash Buffers 1 and 2 produced markedly higher yields of high-purity DNA compared to extractions undertaken with combinations of MGD Kit and WBC protocol wash buffers (Table 2 Trial 2C, Figure 2). As DNA yields and purity were comparable to those obtained using all MKG kit buffers, this combination of buffers was adopted as the SDE protocol, albeit with the remaining need to assess its performance with alternative magnetic bead types to that used in the MGD Kit.

\section{Magnetic Bead Optimisation}

To determine DNA yields and purity using the SDE protocol buffers with any of 4 commercially-available magnetic beads, 4 replicate $200 \mu$ l aliquots of a clarified bulk digest of $300 \mathrm{mg}$ shrimp muscle in $4 \mathrm{ml} \mathrm{SDE} \mathrm{ProK}$ Buffer $1 \mathrm{~b}$ were each added to $300 \mu \mathrm{LDE}$ Lysis buffer and extracted as described in Table 1 using $3 \mu \mathrm{l}, 6 \mu \mathrm{l}, 12 \mu \mathrm{l}$ or $24 \mu$ of each bead type (Table 2 Trial 3, Figure 3). As a control, an equivalent amount of shrimp muscle tissue was extracted using MGD Kit buffers and beads. DNA yields generally increased as bead amounts were increased from $3 \mu \mathrm{l}$ and $24 \mu \mathrm{l}$, except with AccuBeads where DNA yields were highest using $6 \mu \mathrm{l}$ beads and decreased using higher bead amounts. Using the SDE protocol buffer set, DNA yields with either Silanol or Sera-Mag beads equalled or bettered those obtained using the MGD Kit beads. DNA yields were generally somewhat lower using equivalent volumes of AccuBead or Agencourt AMPure-XP beads. Despite this, the purity of DNA obtained using any volume of AccuBeads ( $A_{260 / 280}$ $\mathrm{nm}$ values $>2$ ) surpassed that of DNA extracted using the MGD Kit buffers and beads. While generally $>1.8, A_{260 / 280}$ $\mathrm{nm}$ ratios of DNA extracted using the SDE protocol buffers together with MGD Kit, Silanol or Sera-Mag beads were slightly inferior to those of DNA obtained using the MGD Kit buffers with equivalent amounts of each bead type (1.96 \pm 0.01 to $1.99 \pm 0.02)$.

When the bead volume used in a SDE protocol extraction resulted in an acceptable DNA yield, $A_{260 / 230}$

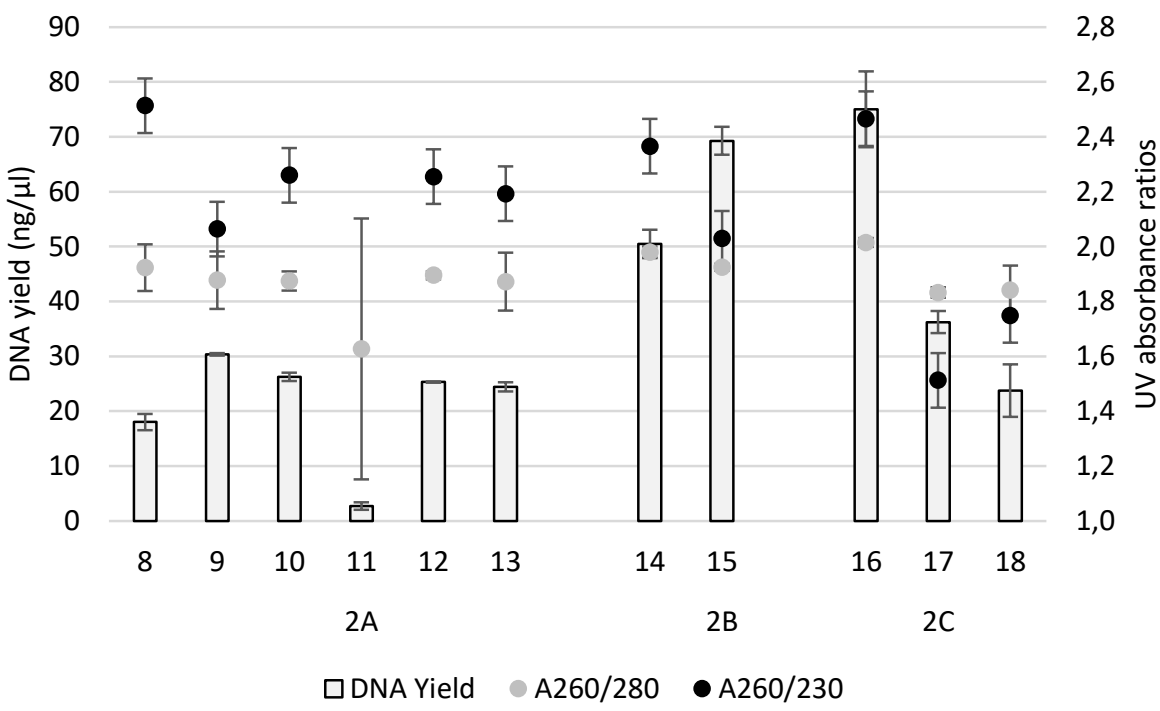

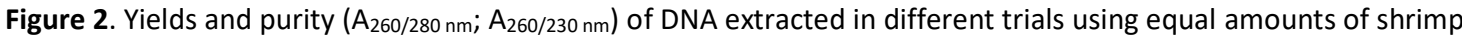
abdominal muscle tissue and various DNA extraction reagent permutations as described in Table 2. Trial 2A compared use of ProK Buffer $1 b$ in combination with the MGD Kit Lysis Buffer $(8,11,13)$ and Wash Buffers $1(8,13)$ and $2(8,11)$ or with the Lysis Buffer $(9,10,12)$, Wash Buffer $1(11,12)$ and Wash Buffer $2(10,13)$ replaced by buffers used in the WBC DNA protocol (Psifidi et al., 2015). Data points represent the mean \pm SD of duplicate extractions. Trial 2B compared use of ProK Buffer $1 \mathrm{~b}$ in combination with the MGD Kit lysis and wash buffers (14) or with the MGD Kit Wash Buffer 1 replaced by SDE protocol Wash Buffer 1 (15). Data points represent the mean \pm SD of 4 replicate extractions. Trial $2 \mathrm{C}$ compared use of ProK Buffer $1 \mathrm{~b}$ in combination with WBC DNA extraction protocol Lysis Buffer $(16,17,18)$, and the various permutations of MGD Kit, WBC DNA protocol and SDE protocol Wash Buffers 1 (17, 18 and 16, respectively) and 2 (18, 17 and 16, respectively). Data points represent the mean \pm SD of 4 replicate extractions. 


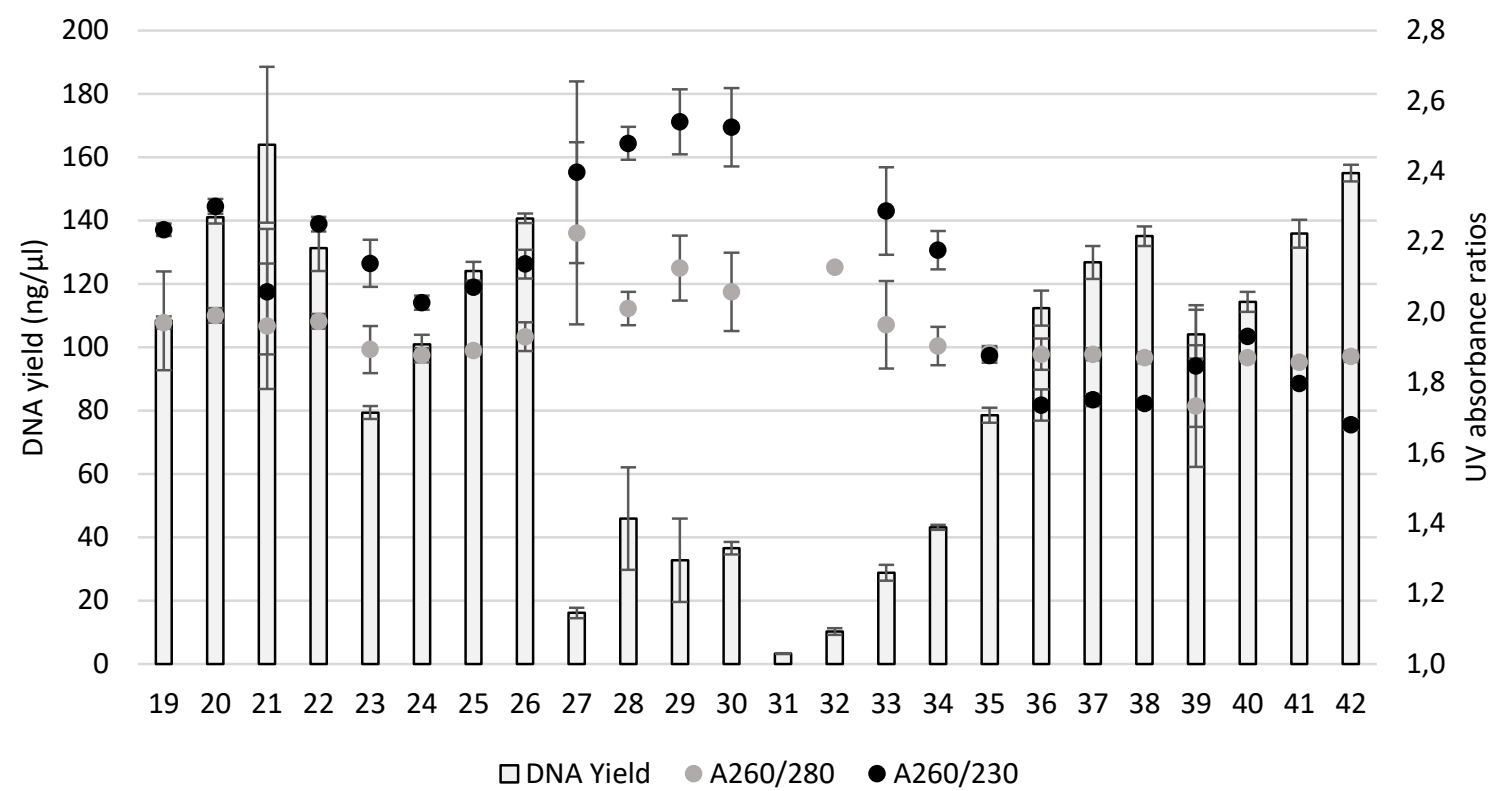

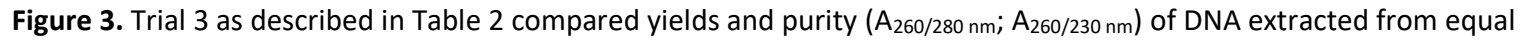
amounts of shrimp abdominal muscle tissue using either all MGD Kit reagents in combination with $3 \mu \mathrm{l}, 6 \mu \mathrm{l}, 12 \mu \mathrm{l}$ or $24 \mu \mathrm{l}$ volumes of Kit magnetic beads (19-22) or the SDE protocol reagent set used with the same volumes of MGD Kit (23-26), AccuBead ${ }^{\mathrm{TM}}$ Silica-coated (27-30), Agencourt AMPure XP (31-34), Silanol (35-38) or Sera-Mag SpeedBead Carboxylate-modified magnetic beads (39-42). Data points represent the mean \pm SD of 4 replicate extractions.

$n m$ ratios of DNA obtained using the same bead volumes were slightly lower with DNA recovered from Silanol or Sera-Mag beads $(1.74 \pm 0.02$ to $1.68 \pm 0.02)$ and slightly higher with DNA recovered from AccuBeads $(2.40 \pm 0.26$ to $2.54 \pm 0.09)$ compared to DNA recovered using the MGD Kit ( $2.06 \pm 0.18$ to $2.30 \pm 0.02$ ) (Figure 3). Overall these data indicated that any of the 4 magnetic bead types tested could be used successfully with the SDE protocol buffer set to extract DNA at acceptable yields and purity, and thus could be selected based on local availability, cost and DNA yield/purity requirements.

\section{SNP genotyping SDE protocol DNA}

DNA extracted from muscle tissue of a single shrimp using either the MGD Kit or the SDE protocol in combination with AccuBead, Silanol or Sera-Mag beads was genotyped in 2 SNP-based MassARRAY panels each employing 60-61 multiplexed pairs of iPLEX PCR primers (Sellars et al., 2012). SNP call rates were high ( $\geq 98 \%$ ) irrespective of extraction method or bead type used (Table 4). Of the 121 SNPs assessed, PCR primer pairs targeting 9 failed across all 94 DNA samples irrespective of the extraction method, indicating that sequence variations existed in the shrimp tested at these genome locations. The other 112 SNPs were generally called accurately with good confidence, except for 1 DNA sample (SM-10) that failed across all 121 SNPs, suggestive of a technical issue with this sample, and for 9 other samples scattered across the different DNA extraction groups in which 1 or 2 of 3 specific SNPs were

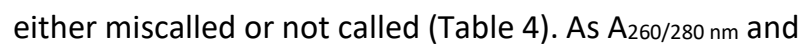

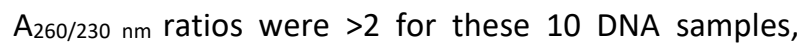
issues with their purity were unlikely. As such, it is possible the aberrant SNP calls arose from the PCR primer pairs targeting these 3 SNPs being somewhat less competent at amplifying DNA and thus more prone to failure in samples where pipetting inconsistencies might have resulted in slightly less DNA template being present. Overall, DNA extracted using the SDE protocol together with any of the 3 bead types tested produced SNP call data that were indistinguishable from DNA extracted using the MGD kit, and that would be more than adequate for pedigree assignment or genetic variability analyses.

\section{SDE Protocol Use to Extract DNA from Salmon Fin Clips}

To assess how well the SDE protocol might perform with other aquaculture species highly reliant on genotyping to manage selected breeding lines, it was used to extract DNA from Atlantic salmon fin clips. When used together with AccuBead, Silanol or Sera-Mag magnetic beads, DNA yields were between $18 \%$ to $37 \%$ of DNA extracted using the MGD Kit (Figure 4). However, $\mathrm{A}_{260 / 280 \mathrm{~nm}}$ ratios equalled or bettered those of DNA

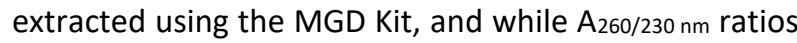
were slightly lower (Figure 4), all were $>2$ indicative of the DNA being highly pure and thus amenable to even demanding downstream processing and genetic analyses (Thermo Fisher 2010). 


\section{Conclusions}

To exploit the use of the automated magnetic bead-based KingFisher ${ }^{\mathrm{TM}}$ Flex Magnetic Particle processor, a buffer set was systematically optimized for the high-throughput extraction of high-purity DNA from shrimp muscle tissue. This shrimp DNA extraction (SDE) protocol was developed to reduce the costs of using commercial DNA extraction kits (Claassen et al., 2013; Dauphin et al., 2009a, 2009b, 2011; Lim et al., 2018; Mertens et al., 2014). This is important as the costs of relying on kits can be prohibitive in breeding programs requiring many thousands of shrimp to be genotyped to assign pedigrees using SNP-based MassARRAY panels (Sellars et al., 2012, Agena Bioscience), or to interrogate large SNP numbers using technologies such as DArTSeq (Diversity Arrays Technology) to associate phenotypes with genotypes. While broadly established from buffers developed to extract DNA from white blood cells (Psifidi et al., 2015), key to recovering high purity DNA from shrimp muscle tissue were wash buffers employing ethanol rather than isopropanol and identifying commercially-available magnetic bead types that would recover DNA at high efficiency. When the SDE protocol was used with AccuBead, Silanol or Sera-Mag magnetic bead types, the call rate for 112 SNPs assessed using a MassARRAY method (Agena Bioscience) was comparable to DNA extracted from shrimp muscle using the MGD Kit buffers and beads (Thermo Scientific) optimized for use with the KingFisher processor. The SDE protocol also proved capable of extracting highpurity DNA from salmon fin tips. Using reagent amounts purchased in sufficient quantities to prepare buffer volumes to extract 500 to $>4000$ tissue samples, and

Table 4. Yields and purity of DNA extracted from shrimp muscle tissue using the MGD Kit or SDE protocol in combination with 3 magnetic bead types and call rates for 121 SNPs determined in MassARRAY-based genotyping analyses

\begin{tabular}{|c|c|c|c|c|c|c|c|}
\hline \multirow{2}{*}{$\begin{array}{l}\text { Bead } \\
\text { Type }\end{array}$} & \multirow{2}{*}{$\begin{array}{c}\text { Tissue } \\
\text { replicates }\end{array}$} & \multirow{2}{*}{$\begin{array}{l}\text { Plate well } \\
\text { position }\end{array}$} & \multicolumn{3}{|c|}{ DNA yield and purity } & \multirow{2}{*}{$\begin{array}{l}\text { SNP } \\
\text { call } \\
\text { rate }\end{array}$} & \multirow{2}{*}{$\begin{array}{c}\text { DNA samples in which } \\
\text { failed/aberrant SNP calls } \\
\text { were detected }\end{array}$} \\
\hline & & & $\begin{array}{c}\text { Mean yield } \\
(\mathrm{ng} / \mu \mathrm{l})\end{array}$ & $\mathrm{A}_{260 / 280 \mathrm{~nm}}$ & $A_{260 / 230 n m}$ & & \\
\hline MGD & $1-24$ & $1-24$ & $171.3 \pm 2.8$ & $2.06 \pm 0.00$ & $2.28 \pm 0.00$ & $99 \%$ & MGD-19A* \\
\hline Accu & $1-24$ & $25-48$ & $49.0 \pm 3.3$ & $2.07 \pm 0.01$ & $2.64 \pm 0.05$ & $98 \%$ & Sil-17A, Sil-21'A,B \\
\hline Sil & $1-24$ & $49-72$ & $120.3 \pm 5.5$ & $2.04 \pm 0.01$ & $2.10 \pm 0.02$ & $100 \%$ & \\
\hline SM & $1-22$ & $73-94$ & $126.1 \pm 1.9$ & $2.04 \pm 0.00$ & $2.24 \pm 0.01$ & $98 \%$ & $\begin{array}{c}\text { SM-7A, SM-9A,B, SM-10 }{ }^{A}, S M- \\
12^{* *}, S M-15^{C}, S M-16^{C}, S M- \\
17^{C}\end{array}$ \\
\hline
\end{tabular}

Abbreviations: MGD = MGD Kit beads, Accu = AccuBead; Sil = Silanol bead; SM = Sera-Mag bead

* Letter codes denote same failed SNP in different DNA sample replicates (numbered sequentially 1 - 22/24)

** No data with all SNPS

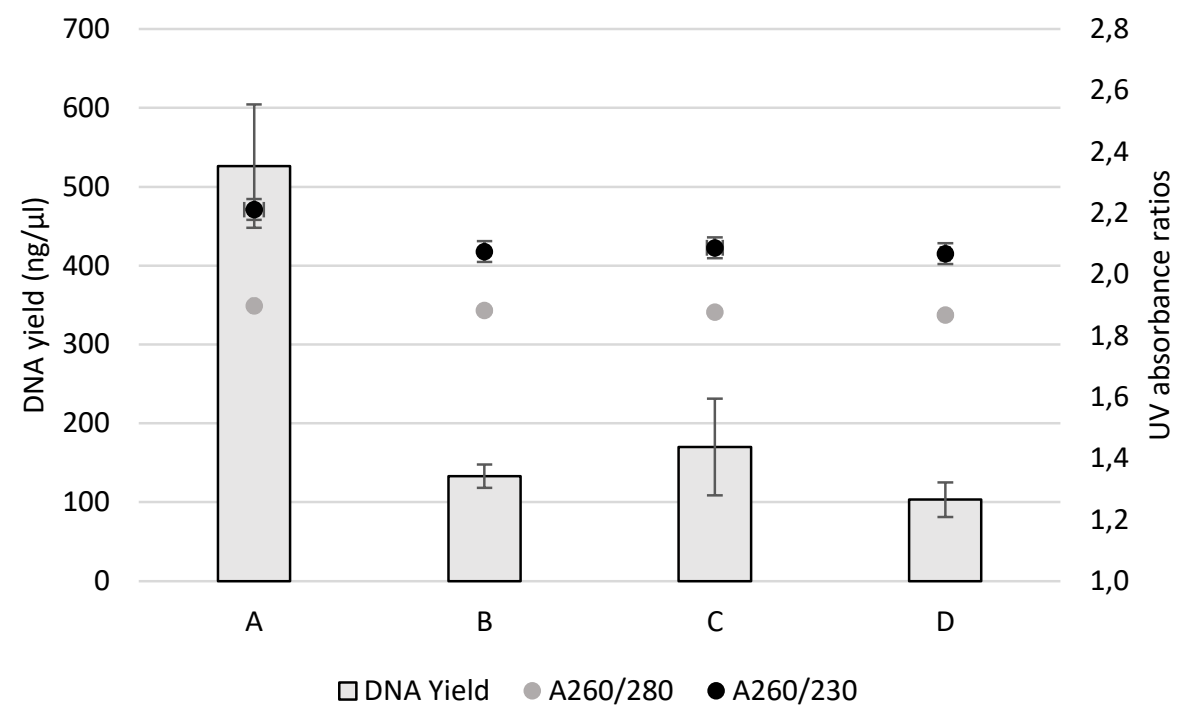

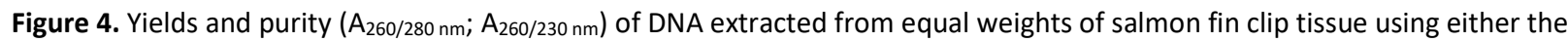
(A) MGD Kit or the SDE protocol using (B) Sera-Mag SpeedBead Carboxylate-modified, (C) Silanol or (D) AccuBead ${ }^{\mathrm{TM}}$ Silicacoated magnetic beads. Data points represent the mean \pm SD of either 4 replicate extractions using equal volumes from a single large ProK tissue digest. 
depending on which bead type is used, the costs per DNA extraction of using the SDE protocol were estimated to be 2- to 3-fold lower than using the MGD or other comparable kits. The SDE protocol thus offers potential to substantially reduce genotyping and pathogen screening costs in research projects and breeding programs aimed at improving the efficiency, quality and outputs of valuable aquaculture species such as shrimp and salmon.

\section{Acknowledgements}

We thank Chris Stratford for providing $P$. monodon and Natasha Botwright for providing salmon tissue samples, Hjinen Marcel at GE Life Sciences for providing sample Sera-Mag SpeedBeads, Martin Peet at Advanced Scientific Products for providing sample Silanol beads and Greg Manderson at Bioneer Pacific for providing sample AccuBeads. The study was funding by the ARC Industrial Transformation Research Program IH130200013.

\section{References}

Ali, N., de Cássia Pontello Rampazzo, R., Dias Tavares Costa, A., \& Aurelio Krieger, M. (2017). Current nucleic acid extraction methods and their implications to point-ofcare diagnostics. BioMed Research International, 9306564. https://doi.org/10.1155/2017/9306564

Alam, M.M.M. \& Pálsson, S. (2016). Population structure of the giant tiger shrimp Penaeus monodon in Bangladesh based on variation in microsatellites and immunerelated genes. Marine Biology Research 12(7), 706-714. https://doi.org/10.1080/17451000.2016.1196820

Baranski, M., Gopikrishna, G., Robinson, N.A., Katneni, V.K., Shekhar, M.S., Shanmugakarthik, J., ... Ponniah, A.G. (2014). The Development of a high-density linkage map for Black tiger shrimp (Penaeus monodon) based on cSNPs. PLoS One 9(1), e85413. https://doi.org/10.1371/journal.pone.0085413

Chomczynski, P., \& Sacchi, N. (1987). Single-step method of RNA isolation by acid guanidinium thiocyanate-phenolchloroform extraction. Analytical Biochemistry 162, 156159. https://doi.org/10.1016/0003-2697(87)90021-2

Claassen, S., du Toit, E., Kaba, M., Moodley, C., Zar, H.J., \& Nicol, M.P. (2013). A comparison of the efficiency of five different commercial DNA extraction kits for extraction of DNA from faecal samples. Journal of Microbiological Methods 94(2):103-110. https://doi.org/10.1016/j.mimet.2013.05.008

Dauphin, L.A., Moser, B.D., \& Bowen, M.D. (2009a). Evaluation of five commercial nucleic acid extraction kits for their ability to inactivate Bacillus anthracis spores and comparison of DNA yields from spores and spiked environmental samples. Journal of Microbiological Methods 76(1), 30-37. https://doi.org/10.1016/j.mimet.2008.09.004

Dauphin, L.A., Hutchins, R.J., Bost, L.A., \& Bowen, M.D. (2009b). Evaluation of automated and manual commercial DNA extraction methods for recovery of Brucella DNA from suspensions and spiked swabs.
Journal of Clinical Microbiology 47(12), 3920-3926. https://doi.org/10.1128/JCM.01288-09

Dauphin, L.A., Walker, R.E., Petersen, J.M., \& Bowen, M.D. (2011). Comparative evaluation of automated and manual commercial DNA extraction methods for detection of Francisella tularensis DNA from suspensions and spiked swabs by real-time polymerase chain reaction. Diagnostic Microbiology and Infectious Disease 70(3), 299-306. https://doi.org/10.1016/j.diagmicrobio.2011.02.010

Dekkers, J.C.M. (2012). Application of genomics tools to animal breeding. Current Genomics 13(3), 207-212. https://doi.org/10.2174/138920212800543057

Deggerdal, A., \& Larsen, F. (1997). Rapid isolation of PCR-ready DNA from blood, bone marrow, and cultured cells, based on paramagnetic beads. BioTechniques 22, 554-557. https://doi.org/10.2144/97223pf02

Dierens, L., Henshall, J., \& Sellars, M.J. (2014). An industry friendly, inexpensive DNA extraction method for Penaeid shrimp that is compatible with Sequenom ${ }^{(R)}$ iPLEX Platinum SNP pedigree genotyping platforms. Aquaculture 433, 102-104. https://doi.org/10.1016/j.aquaculture.2014.06.004

Gallagher, S.R. (2011). Quantitation of DNA and RNA with absorption and fluorescence spectroscopy. Current Protocols in Molecular Biology, Supplement 52(1), A.4K.1-A.4K.4. https://doi.org/10.1002/0471140864.psa04ks52

Guppy, J.L., Jones, D.B., Jerry, D.R., Wade, N.M., Raadsma, H.W., Huerlimann, R., \& Zenger, K.R. (2018). The state of "omics" research for farmed penaeids: advances in research and impediments to industry utilization. Frontiers in Genetics 9, Article 282, 1-27. https://doi.org/10.3389/fgene.2018.00282

Hawkins, T.L, O'Connor-Morin, T., Roy, A., \& Santillan, C. (1994). DNA purification and isolation using a solidphase. Nucleic Acids Research 22, 4543-4544. https://doi.org/10.1093/nar/22.21.4543

Henshall, J.M., Dierens, L., \& Sellars, M.J. (2014). Quantitative analysis of low-density SNP data for parentage assignment and estimation of family contributions to pooled samples. Genetics Selection Evolution 46(1), 51. https://doi.org/10.1186/s12711-014-0051-y

Huerlimann, R., Wade, N.M., Gordon, L., Montenegro, J.D., Goodall, J., McWilliam, S., ... Jerry, D.R. (2018). De novo assembly, characterization, functional annotation and expression patterns of the black tiger shrimp (Penaeus monodon) transcriptome. Scientific Reports 8, 13553, https://doi.org/10.1038/s41598-018-31148-4

Inglis, P.W., Pappas, M.d.C.R., Resende, L.V., \& Grattapaglia, D. (2018). Fast and inexpensive protocols for consistent extraction of high-quality DNA and RNA from challenging plant and fungal samples for high-throughput SNP genotyping and sequencing applications. PLOS One 13, e0206085. https://doi.org/10.1371/journal.pone.0206085

Kang, K., Choi, J., Nam, J.H., Lee, S.C., Kim, K.J., Lee, S.W., \& Chang, J.H. (2009). Preparation and characterization of chemically functionalized silica-coated magnetic nanoparticles as a DNA separator. Journal of Physical Chemistry B 113(2), 536-43. https://doi.org/10.1021/jp807081b.

Levison, P.R., Badger, S.E., Dennis, J., Hathi, P., Davies, M.J., Bruce, I.J., \& Schimkat, D. (1998). Recent developments of magnetic beads for use in nucleic acid purification. 
Journal of Chromatography A, 816, 107-111. https://doi.org/10.1016/S0021-9673(98)00064-8

Li, B., Mou, X., Chen, Z., Chen, H., Deng, Y., Li, S., ... He, N. (2017). The development of a rapid high-quality universal nucleic acid extraction Kit based on magnetic separation. Science China Chemistry 60, 1602-1608. https://doi.org/10.1007/s11426-017-9061-1

Lim, M.Y., Song, E.J., Kim, S.H., Lee, J., \& Nam, Y.D. (2018). Comparison of DNA extraction methods for human gut microbial community profiling. Systematic and Applied Microbiology 41(2), 151-157. https://doi.org/10.1016/j.syapm.2017.11.008.

Lu, X., Luan, S., Cao, B., Meng, X., Sui, J., Dai, ... Kong, J. (2017). Estimation of genetic parameters and genotype-byenvironment interactions related to acute ammonia stress in Pacific white shrimp (Litopenaeus vannamei) juveniles at two different salinity levels. PLoS One 12(3), e0173835. https://doi.org/10.1371/journal.pone

Marko, M.A., Chipperfield, R., \& Birnboim, H.C. (1982). A procedure for the large-scale isolation of highly purified plasmid DNA using alkaline extraction and binding to glass powder. Analytical Biochemistry 12, 382-387. https://doi.org/10.1016/0003-2697(82)90497-3

Mertens, K., Freund, L., Schmoock, G., Hänsel, C., Melzer, F., \& Elschner, M.C. (2014). Comparative evaluation of eleven commercial DNA extraction kits for real-time PCR detection of Bacillus anthracis spores in spiked dairy samples. International Journal of Food Microbiology 170, 29-37.

https://doi.org/10.1016/j.ijfoodmicro.2013.10.022

Nagy, M., Otremba, P., Krüger, C., Bergner-Greiner, S., Anders, P., Henske, B., ... Roewer, L. (2005). Optimization and validation of a fully automated silica-coated magnetic beads purification technology in forensics. Forensic Science International 152(1), 13-22. https://doi.org/10.1016/j.forsciint.2005.02.027

Planella, L., Vera, S.H.M., García-Marín, J-L., \& Roldán, M.I. (2017). An optimized high-quality male DNA extraction from spermatophores in open thelycum shrimp species. Integrative Zoology 12, 421-427. https://doi.org/10.1111/1749-4877.12250

Psifidi, A., Chrysostomos, I., Dovas, C.I., \& Banosa, G. (2010). A comparison of six methods for genomic DNA extraction suitable for PCR-based genotyping applications using ovine milk samples. Molecular and Cellular Probes 24, 93-98. https://doi.org/10.1016/j.mcp.2009.11.001

Psifidi, A., Dovas, C.I., Bramis, G., Lazou, T., Russel, C.L., Arsenos, G., \& Banos, G. (2015). Comparison of eleven methods for genomic DNA extraction suitable for largescale whole-genome genotyping and long-term DNA banking using blood samples. PLoS One 10(1), e0115960. https://doi.org/10.1371/journal.pone.0115960

URL1 https://assets.thermofisher.com/TFSAssets/LSG/manuals/KingFisher_Flex_User_Manual_54 00630_5400640.pdf

URL2 https://assets.thermofisher.com/TFSAssets/LSG/manuals/MAN0012726_MagJET_Genomic_ DNA_UG.pdf
URL3 https://assets.thermofisher.com/TFSAssets/LSG/manuals/Bindlt_4_KingFisherInstrumentsUs erManual.pdf

URL4

https://www.thermofisher.com/search/results?query=k ingfisher+flex+96\&sort=relevancy\&refinementAction=tr ue\&persona=DocSupport \&focusarea=Search\%20All

URL5 Thermo Fisher Scientific (2015). https://assets.thermofisher.com/TFS-

Assets/CAD/Product-Bulletins/TN52646-E-0215MNucleicAcid.pdf

URL6 http://agenabio.com/

Rao, M., Arnold, S.J., \& Cowley, J.A. (2010). High-throughput DNA extraction for PCR-based genotyping of single Penaeus monodon embryos and nauplii. Aquaculture 310,

61-65. https://doi.org/10.1016/j.aquaculture.2010.10.001

Robledo, D., Palaiokostas, C., Bargelloni, L., Martínez, P., \& Houston, R. (2017). Applications of genotyping by sequencing in aquaculture breeding and genetics. Reviews in Aquaculture 10, 670-682. https://doi.org/10.1111/raq.12193.

Rudi, K., Kroken, M., Dahlberg, O.J., Deggerdal, A., Jakobsen, K.S., \& Larsen, F. (1997). Rapid universal method to isolate PCR-ready DNA using magnetic beads. BioTechniques 22, 506-511. https://doi.org/10.2144/97223rr01

Sellars, M.J., Dierens, L., McWilliam, S., Little, B., Murphy, B., Coman, G.J., ... Henshall, J. (2012). Comparison of microsatellite and SNP DNA markers for pedigree assignment in Black Tiger shrimp, Penaeus monodon. Aquaculture Research 45, 417-426. https://doi.org/10.1111/j.1365-2109.2012.03243.x.

Thermo Scientific (2010). T042-Technical Bulletin NanoDrop Spectrophotometers, 260/280 and 260/230 Ratios. http://www.nhm.ac.uk/content/dam/nhmwww/ourscience/dpts-facilitiesstaff/Coreresearchlabs/nanodrop.pdf

Waqairatu, S.S., Dierens, L., Cowley, J.A., Dixon, T.J., Johnson, K.N., Barnes, A.C., \& Li, Y. (2012). Genetic analysis of Black Tiger shrimp (Penaeus monodon) across its natural distribution range reveals more recent colonization of Fiji and other South Pacific islands. Ecology and Evolution 2(8), 2057-2071. https://doi.org/10.1002/ece3.316

Witt, S., Neumann, J., Zierdt, H., Gébel, G., \& Röscheisen, C. (2012). Establishing a novel automated magnetic beadbased method for the extraction of DNA from a variety of forensic samples. Forensic Science International: Genetics 6(5), 539-547. https://doi.org/10.1016/j.fsigen.2012.01.002

Zheng, X., Hoegenauer, K.A., Maeda, A.B., Wang, F., Stelly, D.M., Nichols, R.L., \& Jones, D.C. (2015). Non-destructive high-throughput DNA extraction and genotyping methods for cotton seeds and seedlings. Biotechniques 58(5), 234-243. https://doi.org/10.2144/000114286 